\title{
Contrasting foraging strategies of gannets Morus bassanus at two North Atlantic colonies: foraging trip duration and foraging area fidelity
}

\author{
K. C. Hamer ${ }^{1, *}$, R. A. Phillips ${ }^{1,2}$, J. K. Hill ${ }^{1}$, S. Wanless ${ }^{3}$, A. G. Wood ${ }^{2}$ \\ ${ }^{1}$ Department of Biological Sciences, University of Durham, South Road, Durham DH1 3LE, United Kingdom \\ ${ }^{2}$ NERC British Antarctic Survey, Madingley Road, Cambridge CB3 0ET, United Kingdom \\ ${ }^{3}$ NERC Centre for Ecology and Hydrology, Banchory Research Station, Hill of Brathens, Aberdeenshire AB31 4BY, United Kingdom
}

\begin{abstract}
Seabirds may be able to increase their foraging efficiency by learning the whereabouts of predictable sources of prey and returning repeatedly to these locations. The occurrence of such foraging area fidelity has been little studied, particularly for pelagic species. We used satellite telemetry to study foraging behaviour and foraging area fidelity of individual chick-rearing gannets in the North Sea (at the Bass Rock, SE Scotland) and in the Celtic Sea (at Great Saltee, SE Ireland), 2 areas that differ in the distribution of prey. Foraging ranges of adults covered a wide area of ocean up to a maximum range of $540 \mathrm{~km}$ at the Bass Rock and $240 \mathrm{~km}$ at Great Saltee. At the Bass Rock, individual birds foraged in a single direction or at most in 2 distinct directions, with very similar bearings on successive trips in each direction, significant differences in bearings between individuals and significant repeatability in distances travelled. These results strongly suggest that individuals learned and remembered the locations of feeding sites and used that knowledge on subsequent foraging trips. By contrast at Great Saltee, bearings of successive trips by individuals were much less similar, with highly variable distances to destinations, no differences in bearings among individuals and no significant repeatability in distance travelled. These results indicate a much lower degree of foraging area fidelity at Great Saltee, probably due to a more uniform or less predictable distribution of prey in the Celtic Sea than in the North Sea. Despite marked differences between colonies in distances to trip destinations, durations of foraging trips and foraging area fidelity, the behaviour of birds during foraging trips was very similar at the 2 sites: the average speed of travel during foraging trips was almost identical and birds at both colonies spent about half their time at sea in flight.
\end{abstract}

KEY WORDS: Pelecaniformes · Satellite telemetry · Foraging behaviour · Marine distribution • Information transfer

Resale or republication not permitted without written consent of the publisher

\section{INTRODUCTION}

The foraging behaviour of animals depends largely on the distribution, abundance, mobility and predictability of their food resources (Bell 1991). During the breeding season, locating food is a particular problem for many bird species that have dependent offspring at the nest: their foraging range is limited by the need to

*E-mail: k.c.hamer@durham.ac.uk return repeatedly to the nest, and they need to meet the chicks' nutritional requirements in addition to their own (Carlson \& Moreno 1985, Kacelnik \& Cuthill 1990). Seabirds face particular difficulties in this respect because marine food resources have a sparse, patchy and often unpredictable distribution (Ashmole 1971, Irons 1998). Procellariiform seabirds have welldeveloped olfactory systems and may be able to detect prey at long distances using olfactory cues (Nevitt 2000). However, other species can probably detect prey only at a relatively close range. Thus, adults may 
need to travel long distances from the nest in search of prey, making foraging trips of several hours to several days duration and travelling up to several hundred $\mathrm{km}$ or more from the breeding site (Jouventin \& Weimerskirch 1990, Kooyman et al. 1999, Prince et al. 1999).

Learning how to forage may be a protracted process for seabirds and in most species, sexual maturation is delayed for a number of years, during which time foraging efficiency increases (Burger 1980, Greig et al. 1983, Phillips \& Hamer 1999). Part of this increase may be due to birds learning the whereabouts of spatially and temporally predictable sources of prey (Cairns \& Schneider 1990, Hull et al. 1997). Individuals could increase their foraging efficiency by returning repeatedly to these locations, and such foraging area fidelity has been demonstrated in some coastal-feeding species (Becker et al. 1993, Benvenuti et al. 1998, Irons 1998). However, other species apparently show little foraging area fidelity (Wanless et al. 1990, 1991), and it is not known how widespread such area faithfulness is among different species, or indeed whether it is shown by pelagic-feeding species. Foraging area fidelity could also differ between colonies of a single species in relation to regional differences in the distribution and predictability of prey, but this is not currently proven.

The northern gannet Morus bassanus is the largest pelagic seabird to breed in the North Atlantic (adult body mass ca 3 kg; Nelson 1978). It has an energetically expensive mode of flight which results in high mass-specific energy expenditure during foraging trips (Birt-Friesen et al. 1989). Thus, efficient location of prey is likely to be particularly important to this species. Pelagic fish such as mackerel Scomber scombrus and herring Clupea harengus are important constituents in the diet of gannets (Martin 1989, Hamer et al. 2000). In the North Sea there are a number of traditional commercial fishing grounds for these fish, which are heavily exploited by pelagic stern trawlers during the summer months (April to September: Nelson 1978, Figs 4.4.5-14 in Camphuysen et al. 1995a), corresponding with the gannets' breeding season. Presumably these are sites where the relative abundance and spatial predictability of prey is high, and gannets exploiting these resources, whether catching the fish for themselves or feeding on discards from commercial trawlers, might be expected to display a high degree of foraging area fidelity. By contrast, in the Celtic Sea there are apparently no such traditional summer fishing grounds for pelagic trawlers. Whilst there are large spawning areas for herring along the southern Irish coast, the herring stock is widely distributed offshore during the summer, and only migrates inshore to spawn during November and January (Berrow et al. 1998). This suggests a more uniform distribution of prey in the Celtic Sea during the gannets' breeding season. Therefore, gannets foraging in this region might be expected to display a lower foraging area fidelity.

This study uses satellite telemetry to compare the foraging behaviour of gannets in the North Sea (at the Bass Rock, SE Scotland; $56^{\circ} 6^{\prime} \mathrm{N}, 2^{\circ} 36^{\prime} \mathrm{W}$ ) and in the Celtic Sea (at Great Saltee Island, SE Ireland; $52^{\circ} 7^{\prime} \mathrm{N}$, $6^{\circ} 37^{\prime} \mathrm{W}$ ). These 2 colonies are separated by a minimum distance by sea of about $1200 \mathrm{~km}$. The diets and foraging locations of adults at the Bass Rock were described by Hamer et al. (2000), but individual variation in foraging behaviour and feeding locations was not investigated. Here, we assess how both the degree of foraging area fidelity exhibited by individual adults and the behaviour of birds during foraging trips differed between colonies, and relate this to likely differences in the patchiness of their prey in surrounding waters.

\section{MATERIALS AND METHODS}

Fieldwork took place from 14 June to 28 August 1998 at the Bass Rock and from 24 June to 17 July 1999 at Great Saltee. In both years chick-rearing adults from nests with hatching dates $\pm 2 \mathrm{wk}$ from the mode were captured at the nest using a roach pole with a brass noose. A platform terminal transmitter (PTT; Microwave Telemetry Inc., Columbia, MD) weighing $30 \mathrm{~g}$ (ca $1 \%$ of adult mass) and with a duty-cycle of continuous transmission was then attached to each bird with self-amalgamating tape (RS Components, Corby, UK). To minimise drag during flight and prevent tags being displaced during plunge-diving, tags were attached to the underside of the 4 central tail feathers, close to the base of the tail with the aerial pointing upwards through the feathers. Attachment of tags took approximately $5 \mathrm{~min}$; after release, every bird returned to the nest almost immediately, usually within $5 \mathrm{~min}$. Birds were then tracked for 14 to $23 \mathrm{~d}$ each $($ mean $=16 \mathrm{~d})$, after which time the tag was removed. Tags had no adverse effects on foraging trip durations or adult mass (Hamer et al. 2000).

Data provided by PTTs were processed using the ARGOS facility (CNES, France) and analysed following Hamer et al. (2000). We used only high-quality locations (Class A and above; see Hamer et al. 2000), giving maximum SDs on estimated locations of $6.9 \mathrm{~km}$ at the Bass Rock and $5.9 \mathrm{~km}$ at Great Saltee, which were small in comparison to distances travelled (see 'Results'). Durations of foraging trips were calculated from the time of the first position fix after the bird had left the colony until the time of the first fix after it had returned. This was done only for birds with at least 8 fixes $\mathrm{d}^{-1}$, giving a maximum average error of $\pm 3 \mathrm{~h}$ for departure and arrival times. Average travel 
speed during each of these trips was calculated as twice the slope of the linear regression of maximum distance from the colony plotted against trip duration.

In order to examine movements over shorter intervals within the total foraging ranges of birds, we estimated travel speeds during short sections of each trip as the distance between consecutive pairs of locations divided by the time elapsed between them. In view of the maximum SDs on locations (mentioned earlier), very short intervals between locations could produce erroneous estimates of speed. To avoid this problem we used only pairs of locations at sea separated by more than $1 \mathrm{~h}$.

To examine variation in the foraging locations of individual birds, we used data recorded at average intervals of $\leq 3 \mathrm{~h}$ over a minimum of 6 consecutive foraging trips. This interval was sufficiently short to give an accurate representation of the tracks taken by birds at sea and we used the furthest recorded location from the colony during each of these trips to provide information on trip destinations (Hamer et al. 2000). For each bird from each colony, we calculated a mean destination bearing, and used angular deviation, equivalent to standard deviation in linear data (ranges from 0 to $81.0^{\circ}$; Zar 1984 ) to measure how consistent birds were in their destination bearings on successive trips. Differences in bearings among birds were tested using nonparametric ANOVA of angular distances of bearings from North, following Wallraff (1979) and Zar (1984). We also investigated consistency in distances travelled on successive trips using repeatability analysis (Zar 1984), and quantified this consistency for each bird in terms of the coefficient of variation in maximum distance from the colony (SD $\times 100 /$ mean).

\section{RESULTS}

At the Bass Rock, we obtained a total of 1327 highquality locations $\left(\leq 14 \mathrm{tag}^{-1} \mathrm{~d}^{-1}\right.$ with a mean of $6 \mathrm{tag}^{-1}$ $\mathrm{d}^{-1}$ ) from 17 chick-rearing adults, with $68 \%$ of locations at sea and $32 \%$ at the colony. At Great Saltee we obtained a total of 489 locations of Class A $\left(6 \mathrm{tag}^{-1} \mathrm{~d}^{-1}\right.$ on average) from 5 adults, with $61 \%$ of locations at sea and $39 \%$ at the colony. Less than $2 \%$ of locations at either colony were over mainland, and these were all within one SD of distance (see 'Materials and methods' above) from the coast.

\section{Trip durations and destinations}

Nine birds made 64 trips from the Bass Rock; 5 birds made 54 trips from Great Saltee, with average intervals between locations of $\leq 3 \mathrm{~h}$ over 6 or more consecutive foraging trips (mean $=7.1 ; 10.8$ consecutive trips per bird at the Bass Rock and Great Saltee respectively). At the Bass Rock, mean duration of these trips was $31.3 \mathrm{~h}$ $(\mathrm{SD} \pm 11.0$, range $=13.1$ to $84.0 \mathrm{~h})$ and the mean distance to destination was $223 \mathrm{~km}(\mathrm{SD} \pm 95$, range $=39$ to $540 \mathrm{~km}$ ). Destinations of foraging trips covered a wide area of ocean encompassing $>200000 \mathrm{~km}^{2}$ within the north-west, west and central North Sea (Fig. 1).

Mean trip duration at Great Saltee was significantly shorter than at the Bass Rock $(11.9 \mathrm{~h} \pm 6.7$, range $=2.8$ to $42.8 \mathrm{~h}$; $t$-test using mean values for each bird: $t_{12}=$ $10.5, \mathrm{p}<0.001)$, as was the mean distance to destination $\left(89 \mathrm{~km} \pm 49\right.$, range $=14$ to $238 \mathrm{~km}_{i} t_{12}=9.5, \mathrm{p}<$ 0.001). Destinations of foraging trips from Great Saltee encompassed an area of about $45000 \mathrm{~km}^{2}$ between the coasts of NW Wales, SW England and southern Ireland (Fig. 1). This was about $1 / 4$ of the area covered by birds from the Bass Rock.

\section{Foraging locations of individual birds}

All 9 tagged birds at the Bass Rock travelled SE of the colony, with mean bearings of trips ranging from $111^{\circ}$ to $137^{\circ}$ (Table 1 ). Destinations of these trips were mostly between Farne Deep off the coast of NE England and Dogger Bank in the south-central North Sea (Fig. 2; see Hamer et al. 2000 for locations of bathymetric features). Successive destination bearings for individual birds were very similar (mean angular deviation $=6.9^{\circ}$; Table 1 ) and there were significant differ-

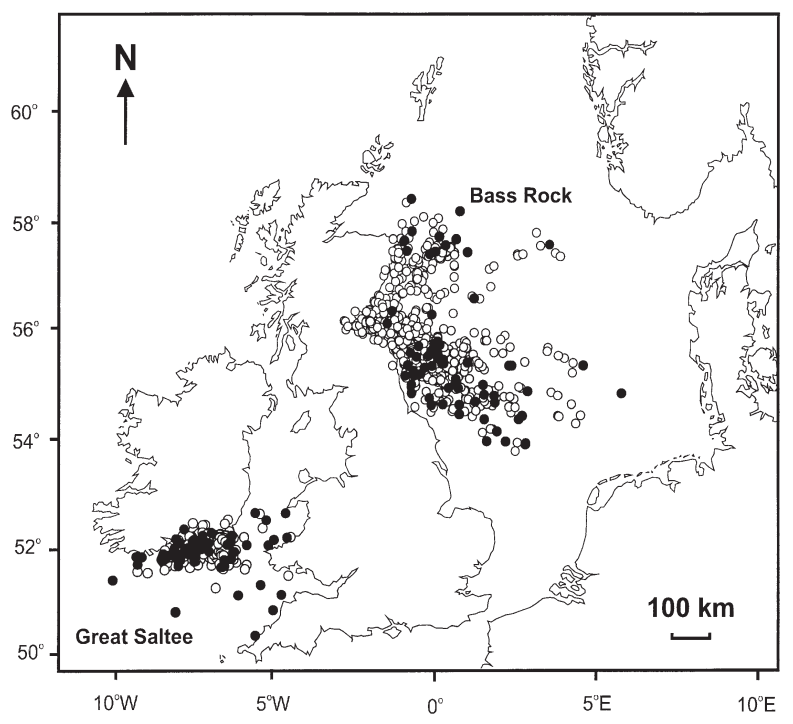

Fig. 1. Morus bassanus. Foraging ranges and destinations of foraging trips by gannets from the Bass Rock, SE Scotland, and Great Saltee, SE Ireland. ( $($ ) Locations of adults at sea; $(\bullet)$ destination bearings of foraging trips 
Table 1. Morus bassanus. Mean bearings and angular deviations for foraging trips by gannets from the Bass Rock, SE Scotland, and Great Saltee, SE Ireland. n: number of foraging trips in each direction for each bird

\begin{tabular}{|c|c|c|c|c|c|c|}
\hline Bird & $\mathrm{n}$ & $\begin{array}{c}\text { Mean } \\
\text { bearing }\left({ }^{\circ}\right)\end{array}$ & $\begin{array}{c}\text { Angular } \\
\text { deviation }\end{array}$ & $\mathrm{n}$ & $\begin{array}{c}\text { Mean } \\
\text { bearing }\left({ }^{\circ}\right)\end{array}$ & $\begin{array}{c}\text { Angular } \\
\text { deviation }\end{array}$ \\
\hline \multicolumn{7}{|c|}{ Bass Rock } \\
\hline 1 & 5 & $\begin{array}{l}\text { - Trips SE } \\
137.4\end{array}$ & 5.7 & 3 & $\begin{array}{c}\text { Trips NE } \\
45.6\end{array}$ & 7.8 \\
\hline 2 & 8 & 110.5 & 7.6 & 0 & - & - \\
\hline 3 & 4 & 130.2 & 5.8 & 3 & 74.6 & 0.2 \\
\hline 4 & 8 & 124.5 & 9.8 & 0 & - & - \\
\hline 5 & 6 & 122.3 & 5.1 & 0 & - & - \\
\hline 6 & 1 & 119.4 & - & 7 & 37.8 & 12.6 \\
\hline 7 & 6 & 111.2 & 7.4 & 0 & - & - \\
\hline 8 & 6 & 111.7 & 8.3 & 1 & 38.1 & - \\
\hline 9 & 4 & 118.2 & 5.8 & 2 & 21.8 & 1.0 \\
\hline \multicolumn{7}{|c|}{ Great Saltee } \\
\hline & & - Trips W & $\overline{105}$ & & - Trips E - & $\overline{360}$ \\
\hline 10 & 8 & 252.4 & 19.5 & 8 & 86.1 & 36.9 \\
\hline 11 & 10 & 242.2 & 11.2 & 3 & 123.9 & 44.1 \\
\hline 12 & 3 & 254.4 & 6.3 & 3 & 104.7 & 48.2 \\
\hline 13 & 10 & 243.8 & 6.8 & 1 & 130.4 & - \\
\hline 14 & 3 & 250.4 & 8.7 & 5 & 131.8 & 43.4 \\
\hline
\end{tabular}

ences in bearings among individuals (Kruskal-Wallis 1-way ANOVA of angular distances from north: $\chi^{2}{ }_{8}=$ $27.6, p=0.001)$. There was significant repeatability in distances travelled by individuals $\left(F_{8,39}=2.4, \mathrm{p}=0.03\right)$ with destinations of approximately half the trips by each bird clustered within a $20 \mathrm{~km}$ radius (Fig. 2), although there was more variation overall in distances

Table 2. Morus bassanus. Distances to destinations of foraging trips from the Bass Rock and Great Saltee. n: number of foraging trips in each direction for each bird

\begin{tabular}{|c|c|c|c|c|c|c|c|c|}
\hline \multirow[t]{2}{*}{ Bird } & \multirow[t]{2}{*}{$\mathrm{n}$} & \multicolumn{3}{|c|}{ Distance $(\mathrm{km})$} & \multirow[t]{2}{*}{$\mathrm{n}$} & \multicolumn{3}{|c|}{ Distance $(\mathrm{km})$} \\
\hline & & Mean & $\mathrm{SD}$ & $\mathrm{CV}$ & & Mean & $\mathrm{SD}$ & $\mathrm{CV}$ \\
\hline \multicolumn{9}{|c|}{ Bass Rock } \\
\hline & & Tri & Ss SE- & & & $T \mathrm{~T}$ & ips NE & \\
\hline 1 & 5 & 167.6 & 48.0 & 28.6 & 3 & 178.7 & 121.0 & 67.7 \\
\hline 2 & 8 & 205.8 & 86.5 & 42.0 & 0 & - & - & - \\
\hline 3 & 4 & 179.5 & 46.7 & 26.0 & 3 & 260.2 & 146.4 & 56.3 \\
\hline 4 & 8 & 192.6 & 63.5 & 33.0 & 0 & - & - & - \\
\hline 5 & 6 & 316.8 & 96.0 & 30.3 & 0 & - & - & - \\
\hline 6 & 1 & 368.0 & - & - & 7 & 196.9 & 76.8 & 39.0 \\
\hline 7 & 6 & 280.3 & 145.6 & 51.9 & 0 & - & - & - \\
\hline 8 & 6 & 238.3 & 121.2 & 50.9 & 1 & 225.0 & - & - \\
\hline 9 & 4 & 299.8 & 66.6 & 22.2 & 2 & 190.5 & 16.3 & 8.6 \\
\hline \multicolumn{9}{|c|}{ Great Saltee } \\
\hline & & $\operatorname{Tr}$ & ps W- & & & & Trips E- & \\
\hline 10 & 8 & 80.7 & 67.9 & 84.1 & 8 & 90.0 & 55.6 & 61.8 \\
\hline 11 & 10 & 90.8 & 41.9 & 46.2 & 3 & 104.8 & 43.2 & 41.2 \\
\hline 12 & 3 & 77.3 & 66.8 & 86.4 & 3 & 89.2 & 80.5 & 90.3 \\
\hline 13 & 10 & 93.1 & 52.7 & 56.6 & 1 & 34.3 & - & - \\
\hline 14 & 3 & 94.1 & 30.3 & 32.2 & 5 & 57.1 & 24.1 & 42.2 \\
\hline
\end{tabular}

travelled (mean CV $=36 \%$; Table 2) than in destination bearings (Table 1 ).

Four of the 9 tagged birds at the Bass Rock foraged only SE of the colony but 5 birds also foraged in one other direction further north, with a minimum of $60^{\circ}$ between trips in different directions (Table 1). Of these 5 birds, 4 foraged to the NE of the colony (mean bearing $=22$ to $46^{\circ}$ ), mostly in the vicinity of Buchan Deep and Halibut Bank off the east coast of Scotland (Fig. 2) and 1 foraged to the east of the colony (mean bearing = $75^{\circ}$; Table 1). As before, successive trips by individual birds had very similar bearings (mean angular deviation $=5.4^{\circ} ;$ Table 1$)$, which differed significantly between individuals (Kruskal-Wallis $\chi_{4}^{2}=10.7, \mathrm{p}=$ $0.03)$, and whilst destinations of about half the trips by each bird clustered together (Fig. 2), distances to destinations were more variable overall (mean CV $=43 \%$; Table 2) than bearings of trips (Table 1). In all 5 cases where birds foraged in 2 directions, there was only a single change of direction between trips.

At Great Saltee, all 5 tagged birds foraged predominantly to the west of the colony ( $65 \%$ of trips; mean bearing 230 to $260^{\circ}$; Table 1). Destinations of all trips were within $100 \mathrm{~km}$ of the southern Irish coast, as far as $10^{\circ} \mathrm{W}$ (Fig. 1). Successive trips by individuals in this direction (Fig. 2) had similar bearings (mean angular deviation $=10.5^{\circ}$; Table 1 ) but there was no difference in mean bearing between individuals (Kruskal-Wallis

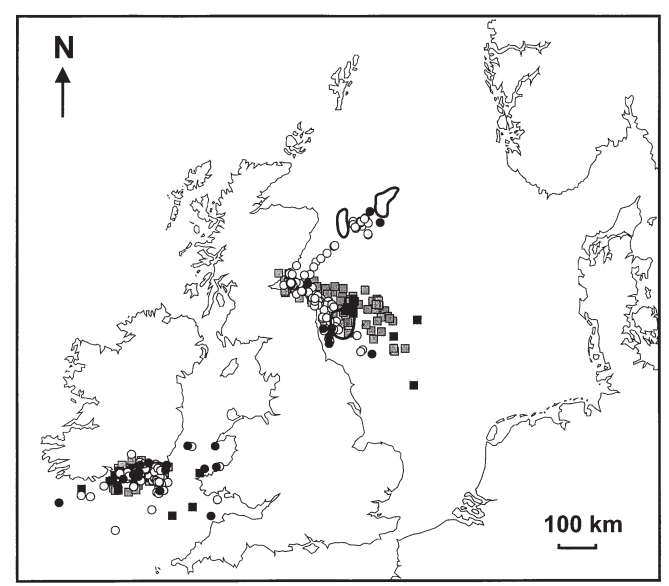

Fig. 2. Morus bassanus. Examples of foraging tracks and destinations of foraging trips by individual chick-rearing adults at the Bass Rock and Great Saltee. Data are shown for 2 representative adults at each colony; typical bearings and angular deviations illustrate observed patterns. $(\circ, \quad$, $)$ foraging tracks; $(\bullet,-)$ destination bearings of trips for each bird. Bass Rock; circles and squares are Bird 1 and Bird 2 respectively in Tables $1 \& 2$. Great Saltee: circles and squares are Bird 10 and Bird 11 respectively. Also shown, locations of 2 commercial fishing grounds in the North Sea, around Buchan Deep and Halibut Bank (off E Scotland) and around Farne Deep (off NE England) 
$\chi^{2}{ }_{4}=3.5, \mathrm{p}=0.5$ ). Distances travelled by each bird were highly variable (mean CV $=61 \%$; Table 2) with no significant repeatability $\left(F_{4,29}=0.1, \mathrm{p}=0.98\right)$. All 5 birds also made trips to the east of the colony (Figs $1 \&$ 2) but there was little similarity in the bearings of successive trips by individuals in this direction (mean angular deviation $=43.2^{\circ} ;$ Table 1 ) and no difference in destination bearings between individuals $\left(\chi_{4}^{2}=3.2, p=\right.$ $0.5)$. Birds switched between initiating trips in different directions on up to $70 \%$ of trips.

\section{Speeds of travel at sea}

Despite the large difference between colonies in trip durations and distances travelled, there was a highly significant relationship between maximum distance from the colony and trip duration at both the Bass Rock (Fig. $3 ; F_{1,67}=988.7, \mathrm{p}<0.0001, \mathrm{r}^{2}=0.94$ ) and Great Saltee (Fig. $3 ; F_{1,58}=305.4, \mathrm{p}<0.0001, \mathrm{r}^{2}=0.84$ ), according to the following equations:

Bass Rock:

Max. distance $(\mathrm{km})=7.05(\mathrm{SE} \pm 0.22) \times$ trip duration $(\mathrm{h})(1)$

\section{Great Saltee:}

Max. distance $(\mathrm{km})=6.88(\mathrm{SE} \pm 0.39) \times$ trip duration $(\mathrm{h})(2)$

Average speed over complete foraging trips was thus equal to 14.1 ( $\mathrm{SE} \pm 0.4) \mathrm{km} \mathrm{h}^{-1}$ (twice the slope of Eq. 1) at the Bass Rock and 13.8 ( $\mathrm{SE} \pm 0.8) \mathrm{km} \mathrm{h}^{-1}$ (from Eq. 2) at Great Saltee. Analysis of covariance indicated no difference in speed between colonies $\left(F_{1,116}=0.6, \mathrm{p}=\right.$ $0.4)$ and this was confirmed by comparison of the mean travel speeds for individual birds (Bass Rock, mean = $15.7 \mathrm{~km} \mathrm{~h}^{-1}, \mathrm{n}=9$ birds, $\mathrm{SD} \pm 2.5$; Great Saltee, mean $=$ $15.0 \mathrm{~km} \mathrm{~h}^{-1}, \mathrm{n}=5, \mathrm{SD} \pm 2.3$; $t$-test using pooled variance estimate: $t_{12}=0.52, \mathrm{p}=0.6$ ).

Speeds of travel over intervals within trips were calculated using consecutive pairs of locations with $>1 \mathrm{~h}$ between them (see 'Methods'). The mean of these values at the Bass Rock (18.1 $\left.\mathrm{km} \mathrm{h}^{-1}, \mathrm{n}=797, \mathrm{SD} \pm 16.6\right)$ was very similar to the mean at Great Saltee $(17.3 \mathrm{~km}$ $\mathrm{h}^{-1}, \mathrm{n}=237, \mathrm{SD} \pm 17.2$ ) and there was no difference in the frequency distribution of travel speeds at the 2 colonies (Fig. 4; Kolmogorov-Smirnov 2-sample test: $Z=0.47, \mathrm{n}=1034, \mathrm{p}=0.98$ ). At both the Bass Rock and Great Saltee, the mean speed during hours of darkness was very low $\left(1.6 \mathrm{~km} \mathrm{~h}^{-1}, \mathrm{n}=30, \mathrm{SD} \pm 1.9\right.$ and $4.0 \mathrm{~km}$ $\mathrm{h}^{-1}, \mathrm{n}=11, \mathrm{SD} \pm 5.4$ respectively), with much higher speeds during daylight $\left(22.3 \mathrm{~km} \mathrm{~h}^{-1}, \mathrm{n}=767, \mathrm{SD} \pm 31.6\right.$ and $21.8 \mathrm{~km} \mathrm{~h}^{-1}, \mathrm{n}=226, \mathrm{SD} \pm 27.3$ respectively). At both colonies, speed of travel during hours of daylight was highly dependent on the interval between fixes (Bass Rock, $F_{1,765}=132.9, \mathrm{p}<0.001, \mathrm{r}^{2}=0.16$; Great

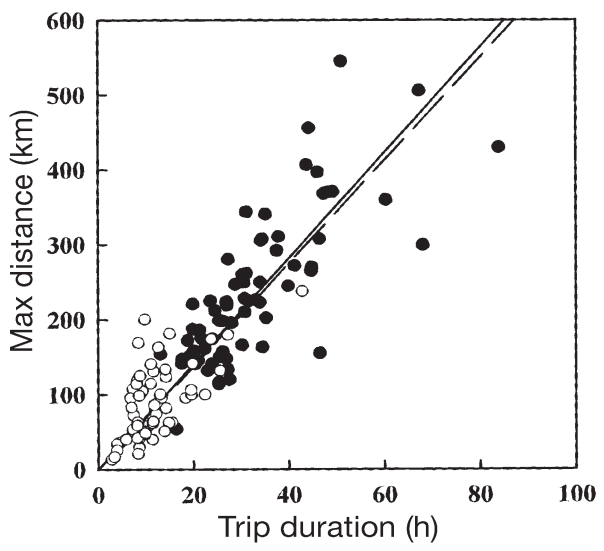

Fig. 3. Morus bassanus. Relationship between distance to destination and foraging trip duration at the Bass Rock $(\bullet,-)$ and at Great Saltee $(0,---)$

Saltee, $F_{1,224}=32.8, \mathrm{p}<0.001, \mathrm{r}^{2}=0.12$ ), according to the following equations:

Bass Rock:

Travel speed $\left(\mathrm{km} \mathrm{h}^{-1}\right)=28.4(\mathrm{SE} \pm 0.9)-1.9(\mathrm{SE} \pm 0.1) \times$ interval $(\mathrm{h})$

Great Saltee:

Travel speed $\left(\mathrm{km} \mathrm{h}^{-1}\right)=32.7(\mathrm{SE} \pm 2.5)-2.6(\mathrm{SE} \pm 0.5) \times$ interval (h)

There was no difference between colonies in either the slopes or the elevations of these equations (analysis of covariance: slope $F_{1,989}=3.1, \mathrm{p}=0.1$; elevation $F_{1,990}=$ $1.1, \mathrm{p}=0.3)$, and travel speed over the shortest intervals $\left(28\right.$ and $33 \mathrm{~km} \mathrm{~h}^{-1}$ at Bass Rock and Great Saltee respectively, Eqs 3 \& 4) was about half average flight speed (55 $\mathrm{km} \mathrm{h}^{-1}$; Pennycuick 1987) in both cases.

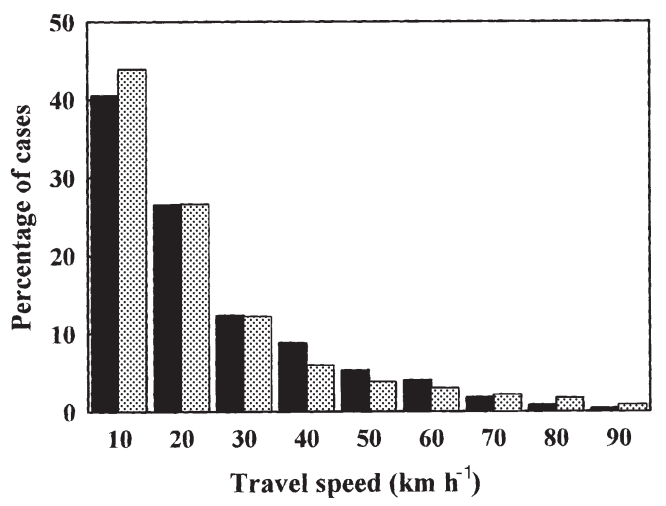

Fig. 4. Morus bassanus. Frequency distribution of travel speeds at sea for gannets at the Bass Rock (solid bars; $\mathrm{n}=797$ ) and Great Saltee (grey bars; $\mathrm{n}=237$ ). Travel speeds were calculated using pairs of locations at sea $>1 \mathrm{~h}$ apart 


\section{DISCUSSION}

PTTs had no discernible adverse effects on adults: trip durations of birds at the Bass Rock wearing PTTs did not differ from those of untagged controls and the body masses of tagged birds after 14 to $21 \mathrm{~d}$ were no different to those of controls (Hamer et al. 2000). At both colonies, there was a lower proportion of highquality locations from the colony than at sea (see 'Results'). This was because signals were blocked or attenuated by physical features of the colony, resulting in poorer visibility of the tags to orbiting satellites when the birds were on land, and not because tagged birds spent any more time at sea than on land.

\section{Foraging ranges at the two colonies}

The foraging ranges of adults at both colonies covered a wide area of ocean up to a maximum range of $540 \mathrm{~km}($ mean $=230 \mathrm{~km})$ at the Bass Rock and $240 \mathrm{~km}$ $($ mean $=90 \mathrm{~km})$ at Great Saltee (Fig. 1). Trips from the Bass Rock were principally in the vicinity of the summer commercial pelagic fishing grounds at Farne Deep and Dogger Bank in the SE, and at Buchan Deep and Halibut Bank in the NE (Camphuysen et al. 1995a, Hamer et al. 2000). Adults travelled about 3 times further on foraging trips from the Bass Rock than from Great Saltee, presumably reflecting differences in the distribution of marine food resources around the 2 colonies. Gannets breeding at the Bass Rock regularly visited Dogger Bank in summer 1994 (Camphuysen et al. 1995b), and so the long trip durations and wide foraging ranges recorded at the Bass Rock in 1998 were probably not unusual for birds at this colony during the 1990s. There are no previous data on foraging ranges of gannets at Great Saltee, but trip durations there in 1999 were similar to those recorded previously for gannets elsewhere (Table 6 in Nelson 1978, Garthe et al. 1999). We are thus reasonably confident that data collected during this study are representative of the trip durations and foraging ranges of birds at the 2 colonies.

\section{Foraging locations of individuals}

Gannets breeding at the Bass Rock foraged either in only one direction (SE of the colony) or at most in 2 distinct directions (SE plus NE or east). Very similar bearings were recorded on successive trips in each direction (Fig. 2) with significant differences in bearings among individuals (Table 1 ). There was only 1 recorded change in direction between consecutive trips. Thus, birds either foraged repeatedly for $\leq 16 \mathrm{~d}$ on a single bearing or foraged for $\leq 12 \mathrm{~d}$ on a single bearing before switching to a different bearing in a markedly different direction from the colony. These results provide strong evidence that individuals learned and remembered the directions to feeding sites and used that knowledge on subsequent foraging trips.

Distances travelled by birds at the Bass Rock (Table 2) indicated significant repeatability but were more variable than bearings of trips (Table 1). Whilst there were conspicuous clusters of foraging trips, about half of all trips either stopped short or went beyond these clusters on a similar bearing (Fig. 2). Moreover, the mean distance between trip destinations within each cluster was about $20 \mathrm{~km}$ (Fig. 2). It has been suggested that the foraging efficiency of seabirds is greatly enhanced by a form of information transfer termed 'network foraging', in which individuals locate feeding sites by observing the flight of other birds as they fly towards a feeding flock (Wittenburger \& Hunt 1985, Harrison et al. 1991, Clode 1993). Thus, the main foraging strategy at the Bass Rock was probably for birds to set out on a bearing to a known feeding site and continue until they either located prey-possibly including commercial trawlers-for themselves or encountered other birds flying towards a feeding flock.

At Great Saltee, all tagged birds foraged west of the colony along the south coast of Ireland and east of the colony in the southern Irish Sea (Table 1, Fig. 2). Successive trips by individuals to the west of the colony had similar bearings but were very variable in terms of distance to destination (Table 2, Fig. 2). No differences in bearings were recorded between individuals and there was no significant repeatability in distance travelled, whilst successive trips east of the colony had very different bearings (Table 1, Fig. 2). These results indicate a much lower degree of foraging area fidelity for gannets breeding at Great Saltee than for those at the Bass Rock, particularly for trips east of the colony. This presumably reflects a more uniform or less predictable distribution of prey in the Celtic Sea than in the North Sea. Adults at Great Saltee switched between initiating trips to the west and east of the colony on up to $70 \%$ of occasions, suggesting that prey were available only intermittently, for instance at certain states of the tide, as was recorded for kittiwakes Rissa tridactyla foraging in Alaska (Irons 1998).

\section{Behaviour during foraging trips}

Despite marked differences between colonies in distances to trip destinations, durations of foraging trips and foraging area fidelity, the behaviour of birds during foraging trips, was very similar at the 2 sites. The average speed of travel during foraging trips was al- 
most identical $\left(14.1 \mathrm{~km} \mathrm{~h}^{-1}\right.$ at the Bass Rock; $13.8 \mathrm{~km} \mathrm{~h}^{-1}$ at Great Saltee, Eqs $1 \& 2$ ), even though average trip duration was three times longer at the Bass Rock. In both cases, travel speed during hours of daylight decreased significantly with increasing time intervals between fixes (Eqs $3 \&$ 4). Presumably this is because travel speeds over longer intervals were more affected by deviations from a straight line course and by time that birds spent feeding and resting on the water (Hull et al. 1997). Over the shortest intervals, where estimates were least affected by deviations from a straight line course, the mean travel speed was $29 \mathrm{~km} \mathrm{~h}^{-1}$ at the Bass Rock (Eq. 3) and $33 \mathrm{~km} \mathrm{~h}^{-1}$ at Great Saltee (Eq. 4). These figures are both close to half the normal flight speed of gannets ( $55 \mathrm{~km} \mathrm{~h}^{-1}$; Pennycuick 1987) indicating that birds at both colonies spent roughly half their time at sea in flight. Garthe et al. (1999) also found from external temperature loggers that birds in Shetland spent about half their time away from the colony in flight, the other half on the sea surface.

Foraging trips by gannets at the Bass Rock were 3 times longer than trips by adults at Great Saltee. Chicks were invariably fed at the end of foraging trips (also recorded by Nelson 1978), indicating that average feeding frequency was 3 times higher at Great Saltee than at the Bass Rock. There was no difference between colonies in chick survival $(\sim 80 \%$ in both cases) but there may have been a difference in chick growth. Alternatively, meals fed to chicks at the Bass Rock may have been larger or have had a higher caloric density than meals at Great Saltee which would compensate for the lower feeding frequency. Further data are now required to examine the sizes of meals fed to chicks, the foraging success of adults at sea and how birds at the 2 colonies allocated food resources between maintaining their own body condition and feeding their chicks.

Acknowledgements. This study was supported by grants from the European Commission Fisheries Directorate (CEC 96-079 and 95/C 76/15) and JNCC (F90-01-154). We thank Sir Hew Hamilton-Dalrymple for access to the Bass Rock and the Neale family for access to Great Saltee, John Croxall and Mike Harris for assistance in developing the project, Bryan Nelson and Oscar Merne for logistic support and advice, and Sue Lewis for assistance with fieldwork.

\section{LITERATURE CITED}

Ashmole NP (1971) Seabird ecology and the marine environment. Avian Biol 1:223-286

Becker PH, Frank D, Sudmann SR (1993) Temporal and spatial pattern of common tern (Sterna hirundo) foraging in the Wadden Sea. Oecologia 93:389-393

Bell WJ (1991) Searching behaviour. Chapman and Hall, London

Benvenuti S, Bonadonna F, Dall'Antonia L, Gudmundsson GA
(1998) Foraging flights of breeding thick-billed murres (Uria lomvia) as revealed by bird-borne direction recorders. Auk 115:57-66

Berrow SD, O'Neill M, Brogan D (1998) Discarding practices and marine mammal by-catch in the Celtic Sea herring fishery. Proc R Ir Acad 98B:1-8

Birt-Friesen VL, Montevecchi WA, Cairns DK, Macko SA (1989) Activity-specific metabolic rates of free-living northern gannets and other seabirds. Ecology 70:357-367

Burger J (1980) The transition to independence and postfledging parental care in seabirds. Behav Mar Anim 4: 366-447

Cairns DK, Schneider DC (1990) Hot spots in cold water: feeding habitat selection by thick-billed murres. Stud Avian Biol 14:52-60

Camphuysen CJ, Calvo B, Durinck J, Ensor K, and 7 others (1995a) Consumption of discards by seabirds in the North Sea. Final report EC DG XIV research contract BIOECO/93/10. NIOZ Rapport 1995-5. Netherlands Institute for Sea Research, Texel

Camphuysen CJ, Heessen HJL, Winter CJN (1995b) Distant feeding and associations with cetaceans of gannets Morus bassanus from the Bass Rock in May 1994. Seabird 17: $36-43$

Carlson A, Moreno L (1985) Central place foraging in wheatears (Oenanthe oenanthe)-foraging itineraries when feeding nestlings. Behav Ecol Sociobiol 16:307-316

Clode D (1993) Colonially breeding seabirds - predators or prey? Trends Ecol Evol 8:336-338

Garthe S, Grémillet D, Furness RW (1999) At-sea activity and foraging efficiency in chick-rearing northern gannets Sula bassana: a case study in Shetland. Mar Ecol Prog Ser 185: 93-99

Greig SA, Coulson JC, Monaghan P (1983) Age-related differences in foraging success in the herring gull (Larus argentatus). Anim Behav 31:1237-1243

Hamer KC, Phillips RA, Wanless S, Harris MP, Wood AG (2000) Foraging ranges, diets and feeding locations of gannets in the North Sea: evidence from satellite telemetry. Mar Ecol Prog Ser 200:257-264

Harrison NM, Whitehouse MJ, Heinemann D, Prince PA, Hunt GL, Veit RR (1991) Observations of multispecies seabird flocks around South Georgia. Auk 108:801-810

Hull CL, Hindell MA, Michael K (1997) Foraging zones of royal penguins during the breeding season, and their association with oceanographic features. Mar Ecol Prog Ser 153:217-228

Irons DB (1998) Foraging area fidelity of individual seabirds in relation to tidal cycles and flock feeding. Ecology 79: 647-655

Jouventin P, Weimerskirch H (1990) Satellite tracking of wandering albatrosses. Nature 343:746-748

Kacelnik A, Cuthill I (1990) Central place foraging in starlings (Sturnus vulgaris). 2. Food allocation to chicks. J Anim Ecol 59:655-674

Kooyman GL, Hull C, Olsson O, Robertson G, Croxall JP, Davis LS (1999) Foraging patterns of polar penguins. In: Adams NJ, Slotow RH (eds) Proc 22nd Int Ornithol Congr, Durban. Birdlife South Africa, Johannesburg, p 2021-2039

Martin AR (1989) The diet of Atlantic puffin Fratercula arctica and northern gannet Sula bassana chicks at a Shetland colony during a period of changing prey availability. Bird Study 36:170-180

Nelson JB (1978) The gannet. T \& AD Poyser, Berkhamstead

Nevitt GA (2000) Olfactory foraging by Antarctic procellari- 
iform seabirds: life at high Reynolds numbers. Biol Bull 198:245-253

Pennycuick CJ (1987) Flight of auks (Alcidae) and other northern seabirds compared with southern Procellariiformes: ornithodolite observations. J Exp Biol 128:335-347

Phillips RA, Hamer KC (1999) Lipid reserves, fasting capability and the evolution of nestling obesity in pelagic seabirds. Proc R Soc Biol Sci Ser B 266:1329-1334

Prince PA, Weimerskirch H, Wood AG, Croxall JP (1999) Areas and scales of interactions between albatrosses and the marine environment: species, populations and sexes. In: Adams NJ, Slotow RH (eds) Proc 22nd Int Ornithol Congr, Durban. Birdlife South Africa, Johannesburg, p 2001-2020

Wallraff HG (1979) Goal-oriented and compass-oriented

Editorial responsibility: Otto Kinne (Editor),

Oldendorf/Luhe, Germany movements of displaced homing pigeons after confinement in differentially shielded aviaries. Behav Ecol Sociobiol 5:201-225

Wanless S, Harris MP, Morris JA (1990) A comparison of feeding areas used by individual common murres (Uria aalge), razorbills (Alca torda) and an Atlantic puffin (Fratercula arctica) during the breeding season. Colon Waterbirds 13: $16-24$

Wanless S, Harris MP, Morris JA (1991) Foraging range and feeding locations of shags Phalacrocorax aristotelis during chick rearing. Ibis 133:30-36

Wittenburger JF, Hunt GL (1985) The adaptive significance of coloniality in birds. Avian Biol 7:1-78

Zar JH (1984) Biostatistical analysis. Prentice-Hall International Inc, New Jersey

Submitted: February 22, 2001; Accepted: April 12, 2001

Proofs received from author(s): December 7, 2001 